\title{
The Diagnosis and Treatment of Acute Acrylonitrile Poisoning: A Clinical Study of 144 Cases
}

\author{
Yuqing Chen, Changfa CHEN, Shenxiong JiN and Lin ZHOU \\ Division of Occupational Medicine, Jinshan Hospital of Shanghai Medical University
}

\begin{abstract}
The Diagnosis and Treatment of Acute Acrylonitrile Poisoning: A Clinical Study of 144 Cases: Yuqing $\mathrm{C}_{\mathrm{HEN}}$, et al. Division of Occupational Medicine, Jinshan Hospital of Shanghai Medical University-An analysis of clinical manifestations and emergency treatment of 144 cases of acute acrylonitrile (ACN) poisoning is reported in this article. It is suggested that the acute poisoning induced by inhalation of $A C N$ at high concentrations for a short duration primarily impairs the central nervous system (CNS), and inhalation of $A C N$ at medium concentrations but for a longer period leads to damage to the liver tissues besides the CNS. In severely poisoned victims, the cardiac muscles may be damaged and in the blood levels glutathione (GSH) is decreased. The rational administration of antidotes including the methemoglobin-producing agent (MHbPA), and the sulfur-providing agent (SPA) is the key to the success of emergency treatment and thus the early recovery of the victims.
\end{abstract}

(J Occup Health 1999; 41: 172-176)

Key words: Acrylonitrile, Poisoning, Methemoglobinproducing agent (MHbPA), Sulfur-providing agent (SPA), Amyl nitrite, Sodium nitrite, Sodium thiosulfate

Recently case reports of acute acrylonitrile (ACN) poisoning are increasing. Much experience has been accumulated in the treatment of this poisoning. Few reports, however, have fully discussed the diagnosis and treatment ${ }^{(-3)}$. The present article reports a clinical study of acute $A C N$ poisoning based on 144 cases with complete data collected in this hospital from Jan. 1977 through Sept. 1994.

\section{Materials and Methods}

This study covered 144 cases (135 males and 9 females). They ranged from 18 to 53 years old (about

Received May 21, 1999; Accepted May 31, 1999

Correspondence to: Y. Chen, Division of Occupational Medicine, The Jinshan Hospital of the Shanghai Medical University, Jin Shan Wei. Shanghai 200540, The People's Republic of China
$90 \%$ being under 30). According to the diagnostic grading as defined in the "Diagnostic Criteria and Principles of Management of Occupational Acrylonitrile Poisoning" (GB7799-87), 42 cases were diagnosed as severe acute ACN poisoning, and 102 cases as mild acute $A C N$ poisoning.

\section{Results}

Causes of the Poisoning. Out of 144 cases, 60 were sporadic poisoning due to minor inadvertent accidents during $\mathrm{ACN}$ production, installation repairing, or $\mathrm{ACN}$ product loading and unloading work; 84 were collective poisoning due to large accidents during the management of the installation of $\mathrm{ACN}$ production equipment. All the victims were poisoned by inhaling ACN leaking out at the scene of accident, and 5 cases were also complicated with allergic contact dermatitis due to exposure of the skin to ACN.

Concentration of $\mathrm{ACN}$ in Air at the Scene of the Accident. Since all our cases resulted from unexpected chemical accidents, samples of air containing ACN at the scene of the accident could not be collected in time for accurate determination of the $\mathrm{ACN}$ concentration. The concentration of $\mathrm{ACN}$ in air, however, could be estimated in the following manner: (1) For the 60 sporadic cases, simulative experiments were made in situ, and the concentrations of ACN in air were found to be $40-560$ $\mathrm{mg} / \mathrm{m}^{3}$; (2) For the 84 cases of collective poisoning, the concentrations of remnant $\mathrm{ACN}$ in air analyzed $5 \mathrm{~h}$ after the accidents were found to be $79-105 \mathrm{mg} / \mathrm{m}^{3}$. Considering the rapidity of $\mathrm{ACN}$ diffusion in air as well as the severity of the poisoning, we assumed, therefore, that the actual concentration of $\mathrm{ACN}$ in air would be over $1000 \mathrm{mg} / \mathrm{m}^{3}$.

\section{Clinical Manifestations}

Latency Period. For 144 cases, the latency of acute $A C N$ poisoning varied inversely with the concentration of $A C N$ in air at the scene of the accident, i.e. the higher the concentration, the shorter the latency period (Table 1). 
Symptoms and Signs. The clinical manifestations in 144 cases involved chiefly the respiratory system, cardiovascular system and particularly the central nervous system (CNS) (Table 2).

\section{Laboratory Examinations}

1. Peripheral White Blood Cell Count. Leukocytosis (WBC $>10 \times 10^{9} / l$ ) with an increase in neutrophils occurred in 66 cases, disappearing on the 4th day after treatment.

2. Liver Function Tests. These were carried out in 120 cases of which 7 cases showed abnormal changes on the

Table 1. Latency period of $A C N$ poisoning

\begin{tabular}{ccrr}
\hline $\begin{array}{c}\text { Concentration } \\
\text { of } \mathrm{ACN} \text { in air } \\
\left(\mathrm{mg} / \mathrm{m}^{3}\right)\end{array}$ & $\begin{array}{c}\text { Duration } \\
\text { of exposure } \\
\text { (Hrs.) }\end{array}$ & $\begin{array}{r}\text { Latency } \\
\text { period } \\
\text { (Hrs.) }\end{array}$ & \multicolumn{1}{c}{$\begin{array}{c}\text { No. of } \\
\text { cases (\%) }\end{array}$} \\
\hline $40-79$ & $1.0-3.5$ & $1.5-6.0$ & $18(12.50)$ \\
$80-100$ & $0.5-2.0$ & $1.0-2.0$ & $24(16.67)$ \\
$>100$ & $0.2-1.0$ & $0.25-1.0$ & $102(70.83)$ \\
\hline
\end{tabular}

5th day after poisoning; a slight increase in ALT (Alanine transaminase), AST (Aspartate aminotransferase) and CG (cholyglycine), up to 2 to 3 times the normal value. All of these abnormal findings disappeared on the 17th day after treatment. All 7 cases with abnormal liver functions were poisoned at low concentrations of $A C N$ in air (40$79 \mathrm{mg} / \mathrm{m}^{3}$ ) but for a longer duration of exposure (3-6 Hrs.); they had no previous history of hepatic diseases, with $\mathrm{HBsAg}$, Anti-HBc-IgM and Anti-HAV-IgM examinations being negative.

3. Determination of Whole Blood Glutathione (GSH). GSH was determined in 90 cases before and on the second day after the administration of SPA, Sodium thiosulfate $\left(\mathrm{Na}_{2} \mathrm{~S}_{2} \mathrm{O}_{3}\right.$ ) (Table 3).

As shown in Table 3, the blood levels of GSH were depressed slightly only in the severe cases. The concentrations of blood GSH were found to be $0.08-0.122$ $\mathrm{g} / l$ (normal value: $>0.163 \mathrm{~g} / l$ ), recovering on the second day after treatment.

4. Measurement of Urine Sulfocyanate. This was performed in 96 cases of which 89 cases revealed an increase in urine sulfocyanate, ranging between 8.0 and $15.6 \mathrm{mg} / l$ (normal value: $7.28 \mathrm{mg} / l$ for smokers and 4.12

Table 2. Clinical manifestations of acute $A C N$ poisoning

\begin{tabular}{lrlr}
\hline Manifestations & Cases $(\%)$ & \multicolumn{1}{c}{ Manifestations } & Cases (\%) \\
\hline Dizziness & $144(100.0)$ & Congesting of pharynx & $105(72.9)$ \\
Headache & $144(100.0)$ & Hoarseness & $13(9.0)$ \\
Feebleness & $144(100.0)$ & Pallor & $108(75.0)$ \\
Sore throat & $87(60.4)$ & Profuse diaphoresis & $95(66.0)$ \\
Chest tightness & $144(100.0)$ & Rough breathing sound & $18(12.5)$ \\
Cough & $16(11.1)$ & Rapid heart rate & $36(25.0)$ \\
Dyspnea & $118(81.9)$ & ECG abnormalities* & $15(10.4)$ \\
Nausea & $133(92.4)$ & High B.P. & $20(12.9)$ \\
Vomiting & $95(66.0)$ & Low B.P. & $5(3.5)$ \\
Abdominal pain & $97(67.6)$ & Liver tenderness & $9(6.5)$ \\
Numbness of limbs & $50(39.7)$ & Hepatomegaly \& splenomegaly & $7(4.9)$ \\
Fainting & $104(72.2)$ & Coma & $7(4.9)$ \\
Convulsion & $46(31.9)$ & Hyperactive knee jerk & $137(95.1)$ \\
\hline
\end{tabular}

*All 15 cases with electrocardiographic abnormalities occurred in severe poisoning. ST-T changes were the chief findings: depression of ST segment $(\geq 0.5 \mathrm{~mm}), 10$ cases; biphasic $T$ wave, 4 cases; increase in $\mathrm{T}$ wave, 1 case. All these abnormalities disappeared after 1 week.

Table 3. Whole blood GSH in acute ACN poisoning

\begin{tabular}{cccc}
\hline & & \multicolumn{2}{c}{ Decrease in blood GSH } \\
\cline { 3 - 4 } $\begin{array}{c}\text { Severity } \\
\text { of poisoning }\end{array}$ & Cases & $\begin{array}{c}\text { before treatment } \\
\text { Cases }(\%)\end{array}$ & $\begin{array}{c}\text { 2 days after treatment } \\
\text { Cases }(\%)\end{array}$ \\
\hline Mild & 60 & $0(0.0)$ & $0(0.0)$ \\
Severe & 30 & $20(66.7)$ & $0(0.0)$ \\
\hline
\end{tabular}


$\mathrm{mg} / \mathrm{l}$ for nonsmokers). All became normal on the 5 th day after treatment.

Treatment. As soon as the victims were removed from the scene of the accident, emergency treatment was started immediately. Antidotes were given promptly, including amyl nitrite inhalation, intravenous injection of $3 \%$ sodium nitrite and $50 \%$ sodium thiosulfate successively, followed by infusion of glucose, ATP, coenzyme A and dexamethasone, along with oxygen inhalation in order to prevent the development of cerebral edema, and to protect the brain and liver cells. Other supportive measures and prophylactic use of antibiotics, if necessary, were also indicated. Although all 144 victims recovered after proper treatment, the speed of recovery varied somewhat due to differences in the selection of antidotes at different doses (Tables 4 and 5).
As shown in Tables 4 and 5, the combined use of amyl nitrite inhalation and intravenous injection of $50 \%$ sodium thiosulfate afforded better therapeutic results both in the mild as well as the severe cases. Moreover, it may be seen that the earlier the use of antidotes, with a slightly larger dose of sodium thiosulfate administered, the sooner the victims recovered. On the other hand, when amyl nitrite was the sole treatment, or the intravenous injection of sodium thiosulfate was delayed for more than 6 hours, the therapeutic effects were poor, and recovery slower.

\section{Discussion}

The Mechanism of ACN Poisoning. ACN, a colorless volatile liquid, is a form of highly toxic organic cyanide. It may greatly endanger the human body in several ways:

(1) ACN is decomposed partly in the body. The

Table 4. Comparison of therapeutic effects of various selections of antidotes in 42 cases of severe ACN poisoning

\begin{tabular}{|c|c|c|c|c|c|}
\hline $\begin{array}{c}\text { Groups } \\
\text { No. }\end{array}$ & Therapy & Cases & $\begin{array}{l}\text { Average duration } \\
\text { for alleviation of } \\
\text { symptoms } \\
\text { (Hrs.) }\end{array}$ & $\begin{array}{l}\text { Average duration } \\
\text { for disappearance } \\
\text { of symptoms } \\
\text { (Hrs.) }\end{array}$ & $\begin{array}{c}\text { Disappearance of } \\
\text { symptoms within } \\
12 \text { h. No. of Cases } \\
(\%)\end{array}$ \\
\hline 1. & $\begin{array}{l}\text { AN inhalation } \\
3 \% \text { SN } 10 \mathrm{ml}, \mathrm{I} . \mathrm{V} . \text { and } \\
5 \% \text { ST } 30 \mathrm{ml}, \mathrm{I} . \mathrm{V} \text {. }\end{array}$ & 15 & 5.0 & 12.0 & $10(66.67)$ \\
\hline 2. & $\begin{array}{l}\text { AN inhalation, and } \\
50 \% \mathrm{ST}, 20 \mathrm{ml} \text {, I.V. }\end{array}$ & 10 & 2.0 & 18.0 & $6(60.00)$ \\
\hline 3. & $\begin{array}{l}\text { AN inhalation, and } \\
50 \% \text { ST } 60 \mathrm{ml} \text {, I.V. }\end{array}$ & 13 & 2.5 & 10.0 & $12(92.31)$ \\
\hline 4. & $50 \% \mathrm{ST} 60 \mathrm{ml}, \mathrm{I} . \mathrm{V}$ & 4 & 3.0 & 14.0 & $2(50.50)$ \\
\hline
\end{tabular}

Note: $\mathrm{AN}=$ amyl nitrite; $\mathrm{SN}=$ sodium nitrite; $\mathrm{ST}=$ sodium thiosulfate.

Table 5. Comparison of therapeutic effects of various selections of antidotes in 102 cases of mild ACN poisoning

\begin{tabular}{|c|c|c|c|c|c|}
\hline $\begin{array}{c}\text { Groups } \\
\text { No. }\end{array}$ & Therapy & Cases & $\begin{array}{l}\text { Average duration } \\
\text { for alleviation of } \\
\text { symptoms } \\
\text { (Hrs.) }\end{array}$ & $\begin{array}{l}\text { Average duration } \\
\text { for disappearance } \\
\text { of symptoms } \\
\text { (Hrs.) }\end{array}$ & $\begin{array}{c}\text { Disappearance of } \\
\text { symptoms within } \\
12 \text { hrs. No. of Cases } \\
(\%)\end{array}$ \\
\hline 1. & $\begin{array}{l}\text { AN inhalation, } \\
3 \% \text { SN } 10 \mathrm{ml} \text {, I.V. and } \\
50 \% \text { ST } 30 \mathrm{ml}, \text { I.V. }\end{array}$ & 12 & 3.0 & 8.0 & $8(66.7)$ \\
\hline 2. & $\begin{array}{l}\text { AN inhalation, and } \\
50 \% \mathrm{ST}, 20 \mathrm{ml} \text {, I.V. }\end{array}$ & 22 & 2.5 & 7.5 & $19(86.4)$ \\
\hline 3. & $\begin{array}{l}\text { AN inhalation, and } \\
50 \% \mathrm{ST} 60 \mathrm{ml} \text {, I.V. }\end{array}$ & 25 & 2.5 & 7.0 & $23(92.0)$ \\
\hline 4. & $50 \% \mathrm{ST} 60 \mathrm{ml}, \mathrm{I} . \mathrm{V}$. & 28 & 2.5 & 10.0 & $21(75.0)$ \\
\hline 5. & $\begin{array}{l}\text { AN inhalation, } \\
\text { and after } 6 \mathrm{Hrs} \text {. } \\
50 \% \text { ST } 30 \mathrm{ml}, \mathrm{I} . \mathrm{V} \text {. }\end{array}$ & 15 & 10.0 & 28.0 & $5(20.0)$ \\
\hline
\end{tabular}

Note: $\mathrm{AN}=$ amyl nitrite; $\mathrm{SN}=$ sodium nitrite; $\mathrm{ST}=$ sodium thiosulfate. 
decomposed cyanide ions $\left(\mathrm{CN}^{-}\right)$react primarily with the iron in the ferric (trivalent) state $\left(\mathrm{Fe}^{3+}\right)$. They react readily with the ferric ions of cytochrome oxidase in mitochondria to form cytochrome oxidase- $\mathrm{CN}$ complex. Once the cytochrome oxdase- $\mathrm{CN}$ complex is formed, the electron-transferring function of the cytochrome oxidase will be lost, so that the biologic oxidation or cellular respiration is inhibited. Hence, ACN produces a cytotoxic hypoxia;

(2) Direct inhibition of the respiratory center by the molecules of $\mathrm{ACN}$ themselves;

(3) ACN reacts with the enzyme containing thiol groups (-SH), inducing metabolic disturbances;

(4) ACN may combine with neurotransmitters, e.g. histamine, 5-HT, dopamine, norepinephrine etc., inducing nervous dystfunction;

(5) ACN may cause severe irritation of exposed skin and mucous membrane, resulting in allergic contact dermatitis and erosive lesions of mucous membrane.

The foregoing passages are in accord with the results of recent reports in the literature ${ }^{4,5}$.

Clinical Manifestations.

(1) ACN primarily incites lesions in the CNS and/or respiratory tract, cardiac muscles and hepatic tissues; the manifestations in 144 cases (Tables 1 and 2) are in accord with those reported in the literature ${ }^{6-8)}$.

(2) Onset and Severity of ACN Poisoning. 132 out of 144 cases were exposed to a higher concentration of $\mathrm{ACN}$ in air, so that the toxic symptoms occurred about $15 \mathrm{~min}$ to $2 \mathrm{~h}$ after inhalation of $\mathrm{ACN}$. The other 12 cases, however, were exposed to relatively lower concentration of $\mathrm{ACN}$, and thus the onset of poisoning was delayed for as much as $6 \mathrm{~h}$. It is suggested that the higher the $\mathrm{ACN}$ concentration inhaled, the earlier the onset of poisoning occurred, and that the larger the toxic dose inhaled, the worse the condition incurred, and vice versa. The doseeffect relationship is significant.

(3) Myocardial and Hepatic Damage. Although all of our cases showed signs of damage due to the CNS, there were but 15 cases of severe poisoning manifesting myocardial damage with ECG abnormalities. Abnormal liver function appeared in only 7 cases of poisoning with low concentration of $\mathrm{ACN}$ in air but longer exposure. This is due to the fact that CNS is particularly susceptible to hypoxia, changes in neurotransmitters and to the direct inhibiting action of $\mathrm{ACN}$ itself. This is why the CNS may be damaged first, long before other organs are involved. The myocardial and hepatic damage occurs only in severe poisoning or though long duration of exposure when hypoxia, enzymatic and metabolic changes develop.

(4) Changes in the Levels of Blood GSH and Urine Sulfocyanate. The whole blood levels of GSH were decreased in 30 cases of severe poisoning, but there were no significant changes in 60 mild cases (Table 3 ). The urine sulfocyanate levels were increased in 89 out of 96 cases $(90.7 \%$ ), but they were not increased in 4 cases of severe poisoning. The findings suggested that the decrease in the blood level of GSH may be taken as an indicator of the severity of poisoning, and that the rise in the urine sulfocyanate level, on the other hand, is merely evidence of recent contact with $\mathrm{ACN}$, but not an indicator of the severity of poisoning, as reported in previous literature.

Treatment of Acute ACN Poisoning. Since the treatment of acute $A C N$ poisoning is emergent and specific, it must be given rapidly and rationally, if it is to obtain a satisfactory result. The common specific antidotes for $\mathrm{ACN}$ are methemoglobin-producing agents (MHbPA), such as amyl nitrite inhalation, $3 \%$ sodium nitrite solution injected intravenously, or $10 \% 4$ dimethylamino-phenol (4-DMAP) injected intramuscularly. The objective in the treatment of acute ACN poisoning is, first of all, to produce a high concentration $(20-30 \%)$ of methemoglobin $\left(\mathrm{Hb}-\mathrm{Fe}^{3+}\right)$ by the administration of MHbPA $\left(\mathrm{Hb}-\mathrm{Fe}^{2+}+\mathrm{NaNO}_{2} \cdot \cdot \mathrm{Hb}-\right.$ $\mathrm{Fe}^{3+}$ ). Methemoglobin competes with cytochrome oxidase $\left(\mathrm{Cyt}-\mathrm{Fe}^{3+}\right)$ for the cyanogen or cyanide ions. As the concentration gradient favors methemoglobin, cyanomethemoglobin ( $\mathrm{Hb}-\mathrm{FeCN})$ is formed and cytochrome oxidase is restored as follows:

$$
\mathrm{Hb}-\mathrm{Fe}^{3+}+\mathrm{Cyt}-\mathrm{FeCN} \longleftrightarrow \mathrm{Hb}-\mathrm{FeCN}+{\mathrm{Cyt}-\mathrm{Fe}^{3+}}^{3+}
$$

Secondary detoxification is then achieved by the intravenous administration of sulfur-providing agent (SPA), sodium thiosulfate which, under the influence of rhodanese, reacts with cyanide ions $\left(\mathrm{CN}^{-}\right)$to form thiocyanate $\left(\mathrm{SCN}^{-}\right)$, a relatively low toxicity product excreted rapidly in urine ${ }^{9.10)}$. The reaction is as follows:

$$
\mathrm{Na}_{2} \mathrm{~S}_{2} \mathrm{O}_{3}+\mathrm{CN}^{-} \frac{\text { rhodanese }}{\mathrm{SCN} \text {-oxidase }} \cdot \mathrm{SCN}^{-}+\mathrm{Na}_{2} \mathrm{SO}_{3}
$$

As the final reaction is slightly reversible through the action of thiocyanate oxidase, it is important to watch the victims carefully in the course of treatment lest the toxic symptoms reappear occasionally after the initial antidotal therapy.

According to our experience with successively cured and recovered cases, it is suggested that the therapeutic effect of detoxicification of ACN may be better when amyl nitrite is administered immediately before the sodium nitrite solution is prepared and injected. Moreover, the detoxicant, SPA must be administered as early as possible, and the dose of sodium thiosulfate is slightly higher (10-25 g/dose) than the usual dose (5-10 $\mathrm{g} /$ dose), so the detoxicificating effect might appear sooner, and the recovery of the victims, earlier. The therapeutic effect is poor and the recovery is slow, if the treatment is merely the sole use of amyl nitrite inhalation, or if the 
use of SPA or sodium thiosulfate is much delayed.

It should be emphasized, therefore, that in acute ACN poisoning, an early administration of the specific antidote, amyl nitrite inhalation, before the injection of sodium nitrite followed closely with SPA, sodium thiosulfate, is the key to the successful treatment and satisfactory recovery of victims. SPA in particular is very effective.

\section{References}

1) Zhang ZY. A report of 12 cases of collective acute acrylonitrile poisoning. Labor Protection in Chemical Industry (Section of Industrial Hygiene \& Occupational Disease). 1986; 7: 23-24 (in Chinese).

2) Wang ZY. A report of 8 cases of acrylonitrile poisoning. Chin J Ind Hyg Occup Dis 1989; 7: 123 (in Chinese).

3) Dong YC, Wu DZ, Yuan HD, et al. Acute acrylonitrile poisoning. A clinical analysis of 15 cases with experience in management at the scene of accident. Occup Med. Guangzhou 1990; 17: 283 (in Chinese).

4) Hasimoto K, Kanai R. Studies on the toxicology of acrylonitrile: Metabolism, mode of action and therapy.
Ind Health $1965 ; 3: 30-46$.

5) Gut I, Kopecky J, Nerudova J. Relationship between acrylonitrile biotransformation, pharmacokinetics and toxicology. A short review. J Ital Med Lav 1981; 3: $131-135$.

6) Xia YX. (Ed.). A Reference Book of Toxicity of Chemical Substances. Shanghai: Shanghai Science and Technology Publisher, 1991; 604-606.

7) Barillo DJ, Goode R, Esch V. Cyanide poisoning in victims of fire: Analysis of 364 cases and reviews of the literature. J Burn care Rehabil 1994; 15: 46-57.

8) Yen-D, Tsai-J, Wang-L-M, et al. The Clinical Experience of Acute Cyanide Poisoning. Am J Emer Med 1995; 13: 524-528.

9) Ding Y, Ni WM. (Eds.). The Handbook of Diagnosis and Treatment of Occupational Diseases, Poisoning and Physical Injuries. Shanghai; Shanghai Medical University Publisher; 1994: 283-284.

10) Mehta C. Antidotal effect of sodium thiosulfate in mice exposed to acrylonitrile. Res Commun Mol Pathol Pharm 1995; 87: 155-165. 